\title{
Prediction of Decreasing Agricultural Land based on Geographic Information System Case Study: Denpasar City
}

\author{
Ni Nyoman Supuwiningsih \\ Department of Computer System \\ STIKOM Bali, Indonesia
}

\author{
Muhammad Rusli \\ Department of Information System \\ STIKOM Bali, Indonesia
}

\begin{abstract}
Agricultural land in Denpasar city from year to year is always decreasing. Based on data from the years 2011-2014, agricultural land decreased significantly with percentage $58.6 \%$. The decline in agricultural land affects agricultural output. The decrease in agricultural land caused by factor, namely the increase in population so that agricultural land is used as a housing or another functions. Seeing this phenomenon due to a lack of information to the public on the impact of agricultural land conversion. The narrow agricultural land in Denpasar will affect the balance of nature, the air will be more crowded and there will be global warming. Based on this analysis then necessary statistical forecasting using method prediction semi trend average which is implemented using the Geographical Information System with ArcView 3.3 as software and digital maps as result. Prediction with this mapping is used to predict the area of agricultural land that would come if the condition is still the same (data used in 2011-2014) so that the government and the general public can know the impact of land conversion and can think of solutions to tackle the agricultural land conversion.
\end{abstract}

\section{Keywords}

Geographical Information System, digital maps, prediction, agricultural land.

\section{INTRODUCTION}

Agriculture is livelihood which be developed in the ancestor in Indonesia and the main livelihood. Agriculture is a strategic sector that an important role in the economy of the Indonesia country, especially to meet the basic needs of the people of Indonesia. Along with the development the majority of society in particular in the city of Denpasar, there was a shift from a farmers' livelihoods to become traders, businessman and etc so in Denpasar city happen agricultural land conversion. Agricultural land from year to year is always decreasing agricultural area in the city of Denpasar. Based on data from the years 2011-2014, agricultural land decreased significantly with percentage $58.6 \%$. The decline in agricultural land affects the outcome of agriculture, with decreasing agricultural land area, the produce of Agricultural also decrease.

The decrease in agricultural land caused by factor, namely the increase in population so that agricultural land is used as a housing or another functions. Other factors is assuming the public that being a farmer is not the main livelihood because his income is uncertain and can not to meet the daily needs so that people are moving to the profession by opening a store on agricultural land and agricultural land to open another business. Based on this phenomenon, it means a lack of information to the public on the impact of agricultural land conversion. The more narrow agricultural land in Denpasar will affect the balance of nature, the air will be more crowded and there will be global warming. Based on the problems it to necessary to analyze the statistical forecasting using method semi trend analysis average (semi-average method) which is implemented using Geographical Information Systems with tools software ArcView 3.3. Geographic Information Systems (GIS) are computer based tools used to collect, store, manipulate and display spatially referenced information [1].

Prediction with this mapping is used to predict the area of agricultural land by using previous data is data in 2011-2014. The purpose of this research is that the government and society in general can think of the impact of land conversion and can think of solutions to tackle the agricultural land conversion.

\section{LITERATURE REVIEW}

Data processing of agricultural land use prediction statistic method semi average. Methods semi average to make the trend by finding the average of the data group [5].

Steps in obtaining the trend line with this method are:

a. Classify data into two parts. If the number is odd, then the data value in the Middle can be omitted or counted twice i.e. 1 part into the first group and 1 part into the second group

b. Calculate the average count first group K1 and K2. K1 is placed in the middle on the Group 1 and $\mathrm{K} 2$ was placed in the middle of the Group 2. The value of K1 and $\mathrm{K} 2$ is a constant value (a) and the layout of the year is the year basis.

c. Calculates the difference between $\mathrm{K} 2-\mathrm{K} 1$, if $\mathrm{K} 2-\mathrm{K} 1>0$ means a positive trend and when $\mathrm{K} 2<\mathrm{K} 1$, the negative trend.

d. Value change in trend (b) obtained by

$$
\mathrm{b}=\frac{K 2-K 1}{\text { tahun dasar } 2-\text { tahun dasar } 1}
$$

e. To know the magnitude of the trend further by entering the value $(\mathrm{X})$ in the equation

$$
\mathrm{Y}=\mathrm{a}+\mathrm{b} \mathrm{X}
$$

B. Analysis of spatial data and non-spatial data

The analysis technique used in this study are:

1. Spatial Data Analysis Techniques 
Techniques spatial data analysis using digitization techniques in the making of spatial data that spatial data 4 districts in the city of Denpasar complete with information on agricultural land the still productive in 2011-2014.

2. The non-spatial data analysis techniques

Conduct analysis of data attributes identified regarding agricultural land of spatial data that had been identified previously so that it can be well integrated between spatial data with non-spatial data

\section{METHODS}

The method used in this study consists the 7 steps:

Step 1. Study of Literature

The first stage of this research is the study of literature, learning theories that support is forecasting techniques, the concept of Geographic Information Systems, Concept ArcView 3.3, studied the results of previous studies which are relevant to this study.

\section{Step 2. Observation of Agricultural Land}

The first phase of this research is the study of literature, the theory behind is forecasting techniques learned, the concept of Geographic Information Systems, Concept ArcView 3.3, studied the results of previous studies which are relevant to this study.

Step 3. Data Collection

This phase of the data collection process of spatial and nonspatial data.

Step 4. Prediction Calculation Process

This phase analysis of relevant forecasting methods used in this study. Forecasting methods used in this research is the analysis of the trend (trend) Average semi (semi-average method).

Step 5. Spatial Data Analysis and non- spatial Analysis

In this stage, the analysis of spatial data and non-spatial data is implemented using ArcView 3.3

Step 6. Process of Layer Identification

At this stage to identify the layer that is used to store spatial data

\section{Step 7. Digitation Process}

At this stage of the digitization process is the conversion from manual to digital (computerized) so as to produce a digital map.

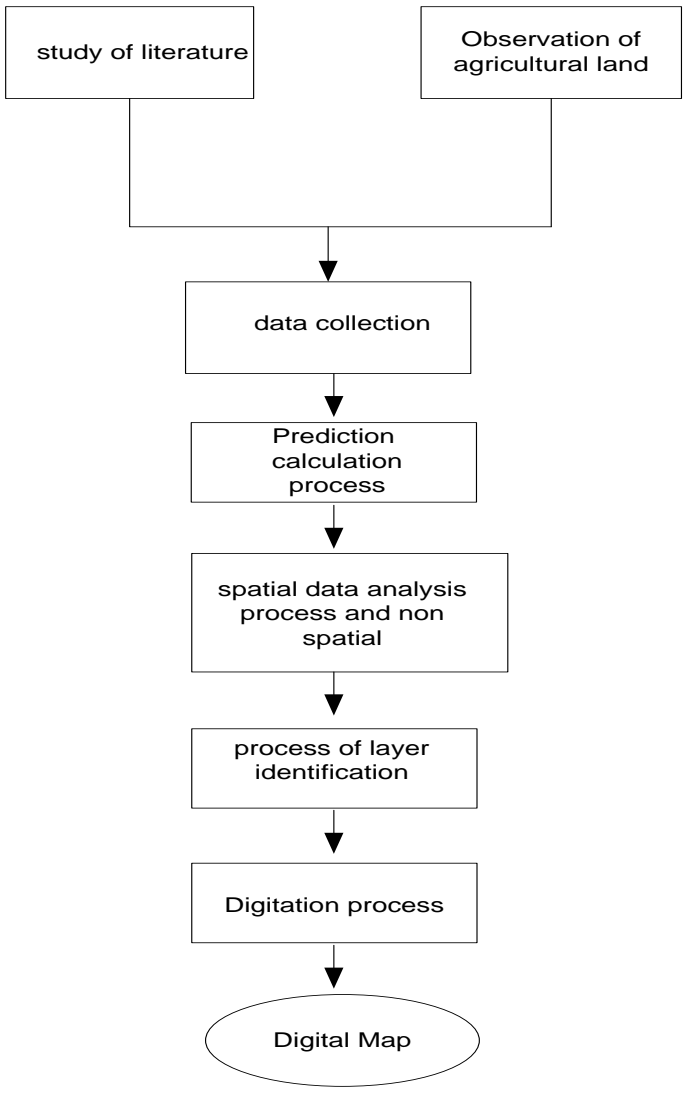

Fig 1 : Systematic Research

\section{RESULT \& DISCUSSION}

\subsection{Result}

Based on the data obtained from the statistical agency of the area of each district in Denpasar as seen table 1. Area of agriculture in Denpasar comprised of rice fields, dry land and plantations. Area of agriculture on each district in the city of Denpasar in 2011-2014 can be seen in Table 2.The data will be processed using the method semi forecasting average.

Table 1. Area of District Denpasar City 2011-2014

\begin{tabular}{|l|l|l|l|l|}
\hline \multirow{2}{*}{ District } & \multicolumn{4}{|c|}{ Area $\left(\mathrm{km}^{2}\right)$} \\
\cline { 2 - 5 } & 2011 & 2012 & 2013 & 2014 \\
\hline East Denpasar & 8.85 & 8.84 & 8.84 & 4.23 \\
\hline $\begin{array}{l}\text { North } \\
\text { Denpasar }\end{array}$ & 8.48 & 8.46 & 8.405 & 4.995 \\
\hline $\begin{array}{l}\text { West } \\
\text { Denpasar }\end{array}$ & 2.56 & 2.56 & 2.843 & 1.353 \\
\hline $\begin{array}{l}\text { South } \\
\text { Denpasar }\end{array}$ & 8.96 & 8.47 & 2.843 & 1.353 \\
\hline
\end{tabular}

Table 2. Area of Agriculture Land 2011-2014

\begin{tabular}{|l|l|l|l|l|}
\hline \multirow{2}{*}{ District } & \multicolumn{4}{|c|}{ Area of Agriculture Land $\left(\mathrm{km}^{2}\right)$} \\
\cline { 2 - 5 } & 2011 & 2012 & 2013 & 2014 \\
\hline $\begin{array}{l}\text { East } \\
\text { Denpasar }\end{array}$ & 8.85 & 8.84 & 8.84 & 4.23 \\
\hline $\begin{array}{l}\text { North } \\
\text { Denpasar }\end{array}$ & 8.48 & 8.46 & 8.405 & 4.995 \\
\hline $\begin{array}{l}\text { West } \\
\text { Denpasar }\end{array}$ & 2.56 & 2.56 & 2.843 & 1.353 \\
\hline $\begin{array}{l}\text { South } \\
\text { Denpasar }\end{array}$ & 8.96 & 8.47 & 2.843 & 1.353 \\
\hline
\end{tabular}


The data in Table 2 treated using semi forecasting average. In accordance with the data in the table it can be concluded that the data tends to decrease, this means that the trends / tendencies down (negative). The formula for the negative trend is:

$$
Y^{\prime}=a-b X
$$

The steps are

1. Divide the data into two groups. The amount of data to be processed there are four (2011-2014), the fourth data is grouped into 2 groups I (2011-2012) and group II (20132014).

2. Calculate the average of each group

$$
\begin{aligned}
& \mathrm{K} 1=(8.96+8.47) / 2=8.715 \\
& \mathrm{~K} 2=(2.843+1.353) / 2=2.098
\end{aligned}
$$

3. Calculate the value changes to the negative trend

$$
\begin{aligned}
\mathrm{b} & =\frac{K 1-K 2}{\text { tahun dasar 2-tahun dasar } 1} \\
& =\frac{8.715-2.098}{2013-2011} \\
& =\frac{6.617}{2} \\
& =3.31
\end{aligned}
$$

4. A trend equation is

a. A trend equation for the base year 2012 is $\mathrm{Y}^{\prime}=$ $8.715-3.31 \mathrm{X}$

b. A trend equation for base year 2014 is $\mathrm{Y}^{\prime}=$ $2,098-3.31 X$

5. Calculate the forecast for 2015 Forecast 2015 using the base year $2012(\mathrm{X}=3)$

$$
\begin{aligned}
\mathrm{Y}^{\prime} & =8.715-3.31 \mathrm{X} \\
& =8.715-3.31 * 3 \\
& =8.715-9.93 \\
& =-1.21
\end{aligned}
$$

6. Calculate the forecast for 2015 Forecast 2015 using the base year $2014(\mathrm{X}=1)$

$$
\begin{aligned}
\mathrm{Y}^{\prime} & =2.098-3.31 \mathrm{X} \\
& =2.098-3.31 * 1 \\
& =2.098-3.31
\end{aligned}
$$$$
=-1.21
$$

7. Calculate the forecast for 2016 Forecast 2016 using the base year $2012(X=4)$

$$
\begin{aligned}
Y^{\prime} & =8.715-3.31 \mathrm{X} \\
& =8.715-3.31 * 4 \\
& =8.715-13.24 \\
& =-4.52
\end{aligned}
$$

8. Calculate the forecast for 2016 Forecast 2016 using the base year $2014(X=2)$

$$
\begin{aligned}
\mathrm{Y}^{\prime} & =2.098-3.31 \mathrm{X} \\
& =2.098-3.31 * 2 \\
& =2.098-6.62 \\
& =-4.52
\end{aligned}
$$

9. Calculate the forecast for 2017 Forecast 2017 using the base year $2012(X=5)$

$$
\begin{aligned}
Y^{\prime} & =8.715-3.31 X \\
& =8.715-3.31 * 5 \\
& =8.715-16.55
\end{aligned}
$$

$$
=-7.83
$$

10. Calculate the forecast for 2017 Forecast 2017 using the base year $2014(\mathrm{X}=3)$

$$
\mathrm{Y}^{\prime}=2.098-3.31 \mathrm{X}
$$

$$
\begin{aligned}
& =2.098-3.31 * 3 \\
& =2.098-9.93 \\
& =-7.83
\end{aligned}
$$

11. Calculate the forecast for 2018 Forecast 2018 using the base year $2012(X=6)$ $\mathrm{Y}^{\prime}=8.715-3.31 \mathrm{X}$

$$
\begin{gathered}
=8.715-3.31 * 6 \\
=8.715-19.86 \\
=-11.14
\end{gathered}
$$

12. Calculate the forecast for 2018 Forecast 2018 using the base year $2014(X=4)$ $\mathrm{Y}^{\prime}=2.098-3.31 \mathrm{X}$

$$
\begin{aligned}
& =2.098-3.31 * 4 \\
& =2.098-13.24 \\
& =-11.14
\end{aligned}
$$

13. Calculate the forecast for 2019 Forecast 2019 using the base year $2012(X=7)$

$$
\begin{aligned}
Y^{\prime} & =8.715-3.31 \mathrm{X} \\
& =8.715-3.31 * 7 \\
& =8.715-23.17 \\
& =-14.45
\end{aligned}
$$

Forecasting 2019 using the base year $2014(X=5)$

$$
\begin{aligned}
Y^{\prime} & =2.098-3.31 X \\
& =2.098-3.31 * 5 \\
& =2.098-16.55 \\
& =-14.45
\end{aligned}
$$

Table 3. Data Prediction Agricultural 2015-2019

\begin{tabular}{|l|l|l|l|l|l|}
\hline \multirow{2}{*}{ District } & \multicolumn{5}{|c|}{ Forecasting Agricultural Area $\left(\mathrm{km}^{2}\right)$} \\
\cline { 2 - 6 } & 2015 & 2016 & 2017 & 2018 & 2019 \\
\hline $\begin{array}{l}\text { East } \\
\text { Denpasar }\end{array}$ & 5.38 & 4.24 & 3.07 & 1.92 & 0.76 \\
\hline $\begin{array}{l}\text { North } \\
\text { Denpasar }\end{array}$ & 5.82 & 4.93 & 4.05 & 3.16 & 2.275 \\
\hline $\begin{array}{l}\text { West } \\
\text { Denpasar }\end{array}$ & 1.87 & 1.64 & 1.41 & 1.17 & 0.94 \\
\hline $\begin{array}{l}\text { South } \\
\text { Denpasar }\end{array}$ & -1.21 & -4.5 & -7.8 & -11.2 & -14.5 \\
\hline
\end{tabular}

Based on the results of research on forecasting using statistical forecasting methods semi average then the result can be seen in Table 3 .

Implementation of the results of research on forecasting changes in agricultural land use software-based GIS ArcView 3.3 as follows figure 1 and figure 2 .

In Figure 1 only displays a map of the area of the agriculture in 2014 in each district in the city of Denpasar. 


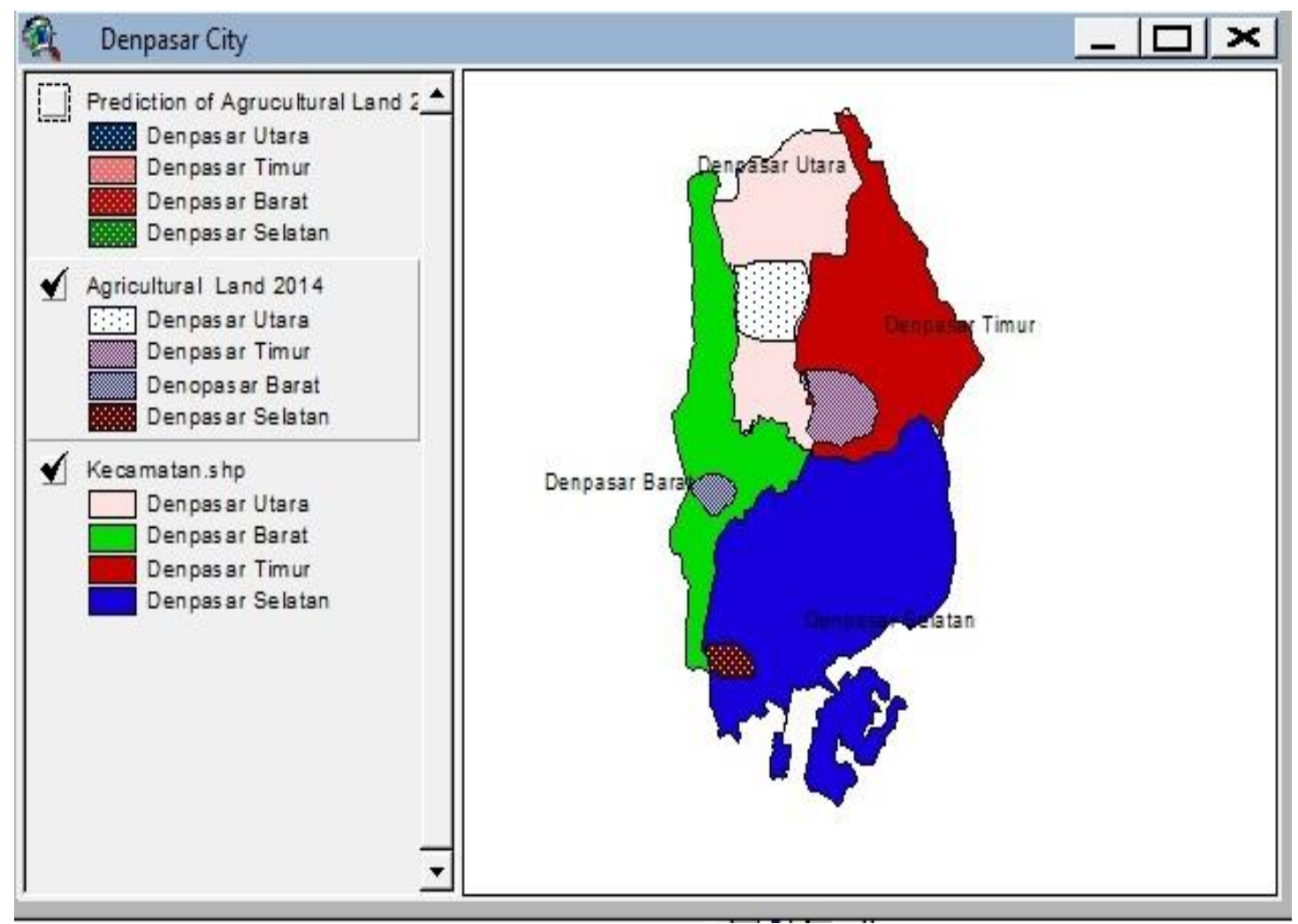

Fig 2: Map of Agricultural Land in 2014

Note:

$\begin{array}{ll}\text { Denpasar Utara } & \text { : North Denpasar } \\ \text { Denpasar Timur } & \text { : East Denpasar } \\ \text { Denpasar Barat } & \text { : West Denpasar } \\ \text { Denpasar Selatan } & \text { : South Denpasar }\end{array}$

Implementation of the results of forecasting of agricultural land in this study is from 2015-2019 of agricultural land gained from years 2011-2014 can be seen in Figure 2. This image displays only forecasting in 2017. The decline in agricultural land in each district of Denpasar to decline significantly, especially in the districts south of Denpasar reached a negative number.

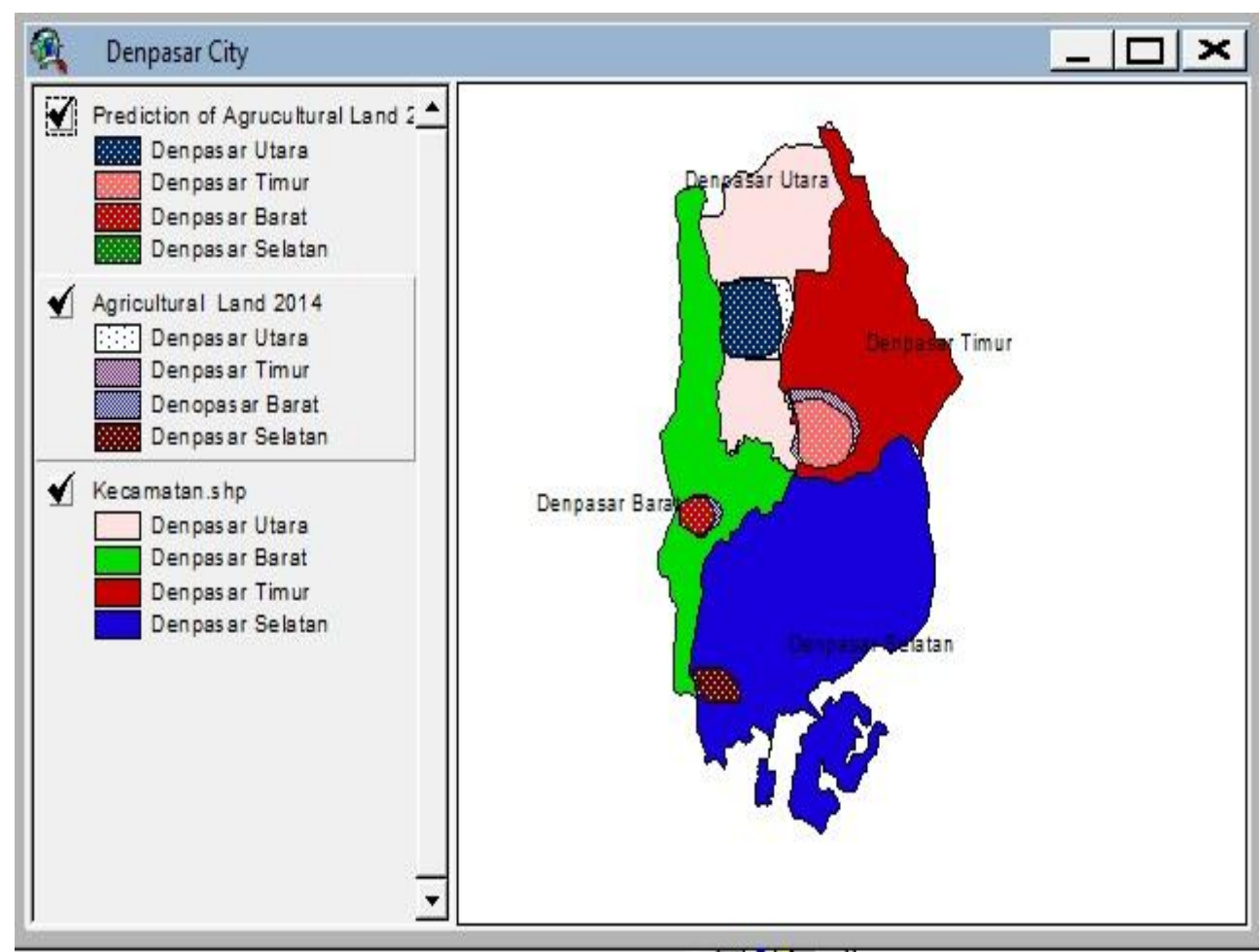

Fig 3: Map Changes Prediction Agricultural Land Year 2017 
Forecasting the results shown are the implementation of the results of forecasting changes in 2017, the map is seen narrowing of agricultural land and more significant decline in agricultural land contained in Denpasar Selatan sub-district reached a negative number.

\subsection{Discussion}

Based on data from the year 2011 that the largest area of agricultural land is in the district of East Denpasar reached $8.85 \mathrm{~km} 2$ approximately $39.6 \%$ of the overall land area while agricultural land is the most narrow region of West Denpasar $2: 56 \mathrm{~km} 2$ reached approximately $10.6 \%$ of the area. Other areas that are north of Denpasar approximately $26.99 \%$ of the agricultural land area while for South Denpasar District which has the most extensive area in comparison with other districts only $17.9 \%$ of the agricultural land area in these districts. Based on the data in 2011 the agricultural area of Denpasar city is very alarming, almost the whole land is used as a residential / business development that is more due to several factors: one of which is centered on the population density as well as the capital city of Denpasar Bali Province.

Based on these data do forecasting agricultural area in Denpasar given very important to maintain the balance of natural ecosystems, the earth is getting no greening then we will lose $\mathrm{O}_{2}$ to breathe and global warning happen before it happens then we are important to know the results of forecasting to anticipate convertion agricultural land.

Implementation with map digital in this research with Arcview 3.3 result of prediction 2017 visible decreasing agricultural land. The result of the prediction in each district of the years 2015-2019 have always experienced a significant decline found in South Denpasar District. Based on the results of these studies are expected to be a concern of Denpasar city government that works with the community to prevent the conversion land to the survival of our children and grandchildren. Imagine that in 2019 agricultural land has decreased drastically, there are at the numbers 0 and negative numbers. If it does not look for solutions then there is global warning, we lack $\mathrm{O}_{2}$, very difficult to live healthy, pollution will be absorbed directly by the body without greening, a disease scattered, seeing such conditions hopefully this study is helpful to all of society to prevent conversion land and immediately find solutions to do modern agriculture.

\section{CONCLUSION \& SUGGESTIONS}

\subsection{Conclusion}

1. Based on the results of extensive research that every year agriculture in each district in the city of Denpasar decreased agricultural land.
2. Decrease the most significant agricultural land is in the district of South Denpasar

3. Implementation of forecasting of agricultural land using ArcView version 3.3 and is very effective as a result of digitization accordance with requirements.

\subsection{Suggestions}

Implementation research with ArcView is desktop software so expect the technology used is published to the web-based community. This research will be conducted at a later stage.

\section{REFERENCES}

[1] Martin J.Bunch, T.Vasantha Kumaran and R.Joseph, "Using Geograhpical Information System (GIS) for Spatial Planning and Environment Management in India : Critical Considerations, International Journal of Applied Science and Technology, vol 2 No.2, pp.40-54, February 2012

[2] Xia Li, Chandana Mitra, Luke Mar Zen and Quichun Yang, "Spatial and Temporal Patterns of Wetland Cover Changes In East Kolkata Wetlands, India from 1972 to 2011" International Journal of Applied Geospatial Research, volume 7 issue 2, April-Juni 2016

[3] Karim Solaimani, "Flood Forecasting Based on Geographical Information system", African Journal of Agricultural Research, volume 4(10), pp 950-956, October 2009.

[4] A.Carrara, F.Guzzetti, M.Cardinal and P.Reichenbach, "Use of GIS Technology in the Prediction and Monitoring of Landslide Hazard", Journal Of The International Society For The Prevention And Mitigation Of Natural Hazards, Volume 20, Issue 2, pp 117-135 November 1999

[5] R. Stella Maragatham,"Trend Analysis of Rainfall Data A Comparative Study of Existing Methods", International Journal of Physics and mathematical, Vol. 2 (1) January-March 2012

[6] Pradeep Kumar Sahu and Rajesh Kumar, "The evaluation of Forecasting Methods for Sales of Sterilized Flavoured Milk in Chhattisgarh", International Journal of Engineering Trends and Technology (IJETT), Volume 8 Number 2, February 2014. 